\author{
Mirjana Tonković, Francesca Dumančić, Maja Anđel \\ Filozofski fakultet, Sveučilište u Zagrebu \\ mirjana.tonkovic@ffzg.hr
}

\title{
Efekt stranog jezika i odlučivanje o moralu
}

\begin{abstract}
Efekt stranoga jezika odnosi se na razlike u ishodima procesa donošenja odluka ovisno o tome odvija li se on na materinskom ili stranom jeziku. Cilj ovog istraživanja bio je ispitati postoji li efekt stranog jezika na procjenjivanje etičnosti postupanja u različitim situacijama, odnosno ispitati utječe li jezik na kojem je moralna dilema prezentirana na procjene prihvatljivosti kršenja moralnih normi. Moralne dileme upotrijebljene u istraživanju opisivale su širok raspon situacija: od onih s kojima se susrećemo u svakodnevnom životu pa do situacija u kojima je potrebno odlučivati o životima ljudi, a razlikovale su se i s obzirom na to koliko su teški moralni prekršaji koje opisuju. U istraživanju su sudjelovali studenti germanistike Filozofskog fakulteta Sveučilišta u Zagrebu, koji su po slučaju raspodijeljeni u dvije skupine, jednu koja je ispunjavala upitnike na hrvatskom jeziku i drugu koje je ispunjavala upitnike na njemačkom jeziku. Istraživanje se sastojalo od tri dijela. Prvi dio činio je Upitnik svakodnevnog morala i socijalnih normi, drugi se dio sastojao od tri moralne dileme koje su opisivale moralne prekršaje različitog stupnja težine, a posljednji dio sastojao se od priča koje su opisivale situacije u kojima je bilo potrebno odlučivati o životima ljudi. Zadatak sudionika bio je procijeniti koliko je opisani postupak moralno pogrešan. Rezultati upućuju na postojanje efekta stranog jezika onda kada se radilo o blažim moralnim prekršajima i onda kada je bilo potrebno odlučivati o životima - sudionici koji su rješavali zadatke na hrvatskom jeziku procjenjivali su opisane situacije više pogrešnima od onih koji su iste zadatke rješavali na njemačkom jeziku. Efekta nije bilo u situaciji velikog moralnog prijestupa kao ni u upitniku svakodnevnog morala i socijalnih normi.
\end{abstract}

\section{Uvod}

Dobro svladan strani jezik obično podrazumijeva širok vokabular, dobro poznavanje gramatike i tečno usmeno i pisano izražavanje na tom jeziku. Kada se dobro služimo nekim stranim jezikom, odgovori na pitanja koje dajemo na tom jeziku trebali bi ovisiti isključivo o sadržaju pitanja, jer smo u mogućnosti razumjeti sve informacije na temelju kojih odlučujemo o odgovoru. Suprotno tome, čitav niz istraživanja provedenih u posljednjih desetak godina govori drugačije. Ta istraživanja pokazuju da u procesu donošenja odluka, zaključivanju ili procjenama rizika nije svejedno odvija li se komunikacija na materinskom ili stranom jeziku. 
Istraživanja koja su se bavila donošenjem odluka koristeći se "paradigmom azijske bolesti«, u kojoj se od sudionika traži da izaberu sigurni, ali djelomični dobitak ili rizičnu opciju u kojoj je moguć potpuni dobitak uz manju vjerojatnost, pokazuju da ljudi u većoj mjeri biraju opciju sigurnog djelomičnog dobitka onda kada je poruka oblikovana tako da se naglašava dobitak (npr. broj ljudi koji može biti spašen uzimanjem lijeka). Nasuprot tome, u situaciji kada je poruka oblikovana tako da se naglašava gubitak (broj ljudi koji sigurno neće biti spašen uzimanjem lijeka), sudionici u većoj mjeri biraju rizičnu opciju potpunog dobitka (u kojoj mogu spasiti sve ljude, ali je šansa za taj ishod relativno mala). Ovaj efekt oblikovanja poruke na odabir vrste lijeka utvrđen je samo onda kada sudionici odgovaraju na materinskom jeziku. Sudionici koji odgovaraju na stranom jeziku jednako često biraju rizičnu opciju bez obzira na način na koji je poruka oblikovana (Keysar, Hayakawa i An 2012; Costa i sur. 2014). Ovi nalazi govore o tome da se procjene rizika razlikuju ovisno o jeziku na kojem je postavljeno pitanje u smislu da upotreba stranog jezika smanjuje averziju prema gubicima povećavajući prihvatljivost rizičnih opcija. Objašnjenje ove pristranosti u mišljenju je to što gubitak izaziva negativne, a sigurni dobitak pozitivne emocije, pa autori ovakve nalaze na stranom jeziku pripisuju ublaženim emocionalnim reakcijama koje onda dovode do veće prihvatljivosti rizičnih opcija. $S$ tim u skladu su i nalazi istraživanja koje je pokazalo da su procjene rizika niza aktivnosti poput putovanja zrakoplovom ili uporabe novih tehnologija niže ako ih sudionici daju na stranom jeziku u odnosu na procjene koje daju na materinskom jeziku (Hadjichristids, Geipel i Savadori 2015). Strani jezik također smanjuje i efekt pristranosti »vruće ruke« koji opisuje precjenjivanje mogućnosti pozitivnog ishoda u kockanju nakon serije pozitivnih ishoda (Gao, Zika, Rogers i Thierry 2015).

Osim procjenom rizika, mnoga istraživanja bavila su se i donošenjem odluka o moralu na materinskom i stranom jeziku. Najčešće upotrebljavane moralne dileme na koje sudionici odgovaraju u takvim zadacima imaju različite varijante, a mogu se svesti na sljedeće pitanje: »Hoćete li žrtvovati jednu osobu kako biste spasili petero ljudi od sigurne smrti?«. Odgovaranje na takvo pitanje pretpostavlja suprotstavljanje dvaju načela: deontološkog, koje zagovara prava pojedinaca i oslanja se na pravila poput »ne nanositi štetu drugima « i utilitarnog, koje podrazumijeva osiguravanje najvećeg dobra za najveći broj ljudi, pri čemu je moguće zanemariti prava pojedinca. Tipičan primjer scenarija u kojem odluka o tome kako ćemo postupiti ovisi o tome vodimo li se deontološkim ili utilitarnim načelima jest dilema nadvožnjaka (eng. footbridge dilemma) kojom su se Costa i sur. (2014) koristili u jednom od prvih istraživanja u kojima se jezik dovodi u vezu s moralnim odlučivanjem. Ovi autori su od dvojezičnih sudionika u istraživanju tražili da zamisle kako se nalaze pokraj pruge po kojoj se vlak kreće velikom brzinom. Na tračnicama ispred vlaka nalazi se petero radnika koji će nastradati ako sudionik nešto ne poduzme. Sudionik se nalazi na nadvožnjaku, zajedno s još jednom krupnom nepoznatom osobom. Jedino što može učiniti da spasi petero radnika jest gurnuti krupnu osobu s nadvožnjaka na tračnice. Težina tijela te osobe dovoljna je da zaustavi vlak i tako 
radnici mogu biti spašeni. Ova je dilema dijelu sudionika prezentirana na materinskom, a dijelu sudionika na jeziku kojega su usvojili kasnije u životu. Od sudionika kojima je dilema prezentirana na materinskom jeziku, njih oko $20 \%$ je odgovorilo da bi gurnuli krupnu osobu s nadvožnjaka, dok je taj postotak bio dvostruko veći kod sudionika kojima je dilema prezentirana na stranom jeziku. $S$ druge strane, odgovori na scenarij u kojem je moguće spasiti radnike upotrebom skretnice koja će vlak preusmjeriti na drugi kolosijek na kojemu je samo jedan radnik, a ne guranjem krupne osobe pod vlak, nisu se razlikovali na materinskom i stranom jeziku. Ovaj se nalaz tumači time što odluka o guranju stranca, u odnosu na odluku o uporabi skretnice, ima izraženiju emocionalnu komponentu. Strani jezik povećava emocionalnu distancu, što dovodi do veće vjerojatnosti odgovaranja vođenog utilitarnim načelima (Costa i sur. 2014). Geipel, Hadjichristidis i Surian (2015a) potvrdili su prethodne nalaze koristeći se objema inačicama dileme nadvožnjaka, ali je do nižih procjena emocionalnosti opisanih scenarija na stranom jeziku došlo u obje inačice dileme nadvožnjaka. Dodatno, efekt stranog jezika nije bio posredovan tim nižim procjenama emocionalnosti. Dodavanjem još nekih scenarija autori zaključuju da do efekta jezika na procjene moralnosti dolazi zbog manje istaknutosti socijalnih $i$ moralnih normi na stranom jeziku. Isti su autori ovakvo objašnjenje potkrijepili još jedim istraživanjem u kojemu su se koristili nizom pitanja o prihvatljivosti kršenja različitih socijalnih i moralnih normi, kao što je dobrovoljni incest između odraslih osoba, objedovanje vlastitog psa kojeg je na ulici usmrtio automobil, čišćenje kupaonice nacionalnom zastavom ili varanje na ispitu. Rezultati su pokazali da sudionici na pitanje koliko je pogrešno svako od opisanih ponašanja odgovaraju nižim procjenama kada je pitanje postavljeno na stranom u odnosu na situaciju kada je ono postavljeno na materinskom jeziku. Manje su osuđivali i neka blaža kršenja svakodnevnih normi poput bezopasnog laganja ili vožnje nakon konzumacije jednog alkoholnog pića (Geipel, Hadjichristidis i Surian 2015b).

Osim već navedenih mogućih posljedica uporabe stranog jezika, jedno je istraživanje pokazalo i to da strani jezik potiče evaluaciju događaja više na temelju njihovih ishoda, a manje na temelju namjera (Geipel, Hadjichristidis i Surian 2016). U tom su istraživanju sudionici koji su odgovarali na stranom jeziku (u odnosu na one koji su odgovarali na materinskom) događaje s pozitivnim ishodom procjenjivali još pozitivnijima, iako takav ishod nije bio jedini povod opisanih događaja, dok su istovremeno događaje s negativnim ishodima procjenjivali još negativnijima, iako namjera aktera u priči nije bila negativna. Međutim, ovaj efekt nije potvrđen u kasnijim provjerama (Costa i sur. 2019).

Dominantno objašnjenje efekta koji strani jezik ima na procese donošenja odluka ili zaključivanje je ono koje se oslanja na razlike u emocionalnosti stranog nasuprot materinskog jezika. Čak je i na bazičnim kognitivnim procesima kao što su pamćenje ili brzina obrade informacija moguće uočiti razlike ovisno o jeziku na kojem se obavlja zadatak. Tako je, primjerice, razlika u pamćenju emocionalnih riječi u odnosu na neutralne manje izražena kada se radi o drugom (Anooshian i Hertel 
1994) ili trećem jeziku (Rasanen i Pine 2012), a tabu ili seksualno eksplicitne riječi lakše je ignorirati ako su napisane na stranom jeziku (Colbeck i Bowers 2012). Posljedično, ne iznenađuje nalaz da dvojezični govornici mogu duže govoriti o temama koje izazivaju osjećaj srama ako se razgovor odvija na drugom jeziku (Bond i Lai 1986). Osim na bihevioralnim mjerama, manja emocionalnost drugog jezika vidi se i u smanjenim reakcijama autonomnog živčanog sustava i slabijoj elektrodermalnoj reakciji (Harris, Ayçiçegi i Gleason 2003; Harris, Gleason i Ayçiçegi 2006). Najizraženije razlike u ovim istraživanjima su, očekivano, dobivene onda kada je prvi jezik dominantan, a drugi naučen kasnije i sudionici ga manje dobro govore. $U$ istraživanjima u kojima je primijenjen emocionalni Stroopov zadatak nije dobivena razlika u razini interferencije emocionalnih riječi ovisno o jeziku (Eilola, Havelka i Sharmaa 2007), ali su riječi koje izazivaju emocije rezultirale intenzivnijim reakcijama autonomnog živčanog sustava kada su bile prikazane na materinskom jeziku (Eilola i Havelka 2011; za pregled istraživanja o razlikama u emocionalnosti jezika vidi Pavlenko 2012).

Faktori koji pridonose razlikama u emocionalnom doživljavanju na prvom i drugom ili trećem jeziku svakako su dob usvajanja drugog jezika (u smislu da što je jezik ranije usvojen, razlike su manje), te znanje jezika i čestota upotrebe, koji su svi međusobno povezani. Na primjer, u istraživanju Čavar i Tytus (2017) nisu dobivene razlike u donošenju odluka o moralu na stranom i materinskom jeziku, ali su sudionici, za razliku od drugih istraživanja, bili dvojezični govornici čiji je drugi jezik službeni jezik zemlje u kojoj žive pa se njime redovito koriste u svakodnevnim situacijama. Faktor koji je također važan, a može biti neovisan o ovim navedenima, jest način, odnosno kontekst usvajanja drugog jezika. Materinski jezik usvajamo u okolini koja nam omogućava povezivanje riječi koje učimo sa socijalnim situacijama i tjelesnim stanjima koja su važan dio emocionalnog iskustva. $S$ druge strane, strani se jezik često usvaja u kontekstu učionica, koje su manje emocionalne i u kojima je jezik kojim izražavamo emocije teško izravno povezati s proživljenim emocionalnim iskustvom, čak i u uvjetima u kojima ga upotrebljavamo često - kada intenzivno učimo strani jezik. Neki autori smatraju da će zbog toga biti najviše razlika upravo u izazivanju neugodnih emocija na stranom jeziku jer su one te koje su rijetke u kontekstu učenja jezika u učionici, za razliku od ugodnih, koje se tu ipak pojavljuju (Sheikh i Titone 2015). Da je upravo supresija neugodnih emocija ta koja pridonosi razlikama u odlučivanju o moralu na stranom jeziku potvrđuje i istraživanje Hayakawe i sur. (2017), u kojem su pokazali da je za efekt odgovorna manje intenzivna emocionalna reakcija vezana uz kršenje deontoloških načela.

Uzmemo li u obzir važnost konteksta u kojem se drugi jezik uči i koristi, moguće je zamisliti da dvoje ljudi koji jednako dobro govore isti drugi jezik različito intenzivno doživljavaju emocije na tom drugom jeziku jer jedan od njih drugi jezik koristi na poslu, a drugi u obiteljskom okruženju, koje je obično bogatije emocijama u odnosu na ono poslovno (Caldwell-Harris 2015). Uporaba drugog jezika u pri- 
rodnom okruženju i u socijalnim interakcijama s drugim ljudima najbrži je put do veće emocionalnosti jezika koji učimo.

Osim već navedenih mogućih objašnjenja efekta stranog jezika na donošenje odluka i zaključivanje putem smanjene emocionalnosti stranog jezika ili manje važnosti socijalnih normi (Geipel, Hadjichristidis i Surian 2015a), u literaturi je moguće pronaći još neka. Strani jezik povećava psihološku distancu (Fujita, Henderson, Eng, Trope i Liberman 2006), što dovodi do obrade na apstraktnijoj razini, davanja veće važnosti koristima nego rizicima i ishodima nego namjerama. To bi moglo dobro objasniti i prethodno opisane nalaze istraživanja o procjenama rizika, stavljanju naglaska na ishode, kao i to da način na koji je oblikovana poruka ima manje utjecaja na stranom jeziku jer površne promjene nisu toliko važne ako o problemu razmišljamo s distance na apstraktnijoj razini. Hayakawa i Keysar (2018) su pokazali da upotreba stranog jezika potiče stvaranje manje živih mentalnih predodžbi, čime su djelomično objasnili utjecaj stranog jezika na donošenje odluka o moralu.

Budući da trenutno ne postoji slaganje oko toga koji su mehanizmi u podlozi djelovanja efekta stranog jezika, kao ni to pod kojim uvjetima se on javlja, jasno je da postoji potreba za daljnjim istraživanjima na ovom novom i dinamičnom području. Koliko je nama poznato, istraživanja ovog tipa do sada nisu provedena u Hrvatskoj na hrvatskom jeziku u kombinaciji s nekim od drugih jezika koji se mogu učiti u našoj zemlji. O važnosti istraživanja koja povezuju odluke o moralu i jezik govori i činjenica da se u Europskoj uniji u današnje vrijeme više od 73\% ljudi u dobi od 25 do 34 godine služi najmanje jednim stranim jezikom (Eurostat 2019). Usto, sve više ljudi svakodnevno koristi strani jezik u poslovne i privatne svrhe, na njemu razmišljaju, komuniciraju i donose odluke. Dosad provedenim istraživanjima može se uputiti važan prigovor koji se odnosi na odabir scenarija. Oni najčešće opisuju ekstremne situacije s kojima se prosječna osoba najvjerojatnije neće susresti pa je upitno koliko se rezultati mogu generalizirati na moralne dvojbe s kojima se susrećemo u svakodnevnom životu. Također, moralne dvojbe moguće je razlikovati prema težini prijestupa opisanog u nekom hipotetskom događaju. Zbog toga smo u ovom istraživanju uključili i scenarije i moralne dvojbe bliske onima s kojima se susrećemo u svakodnevnom životu te smo ih razlikovali i s obzirom na težinu opisanog moralnog prijestupa.

\section{Cilj istraživanja}

Cilj ovog istraživanja bio je provjeriti razlikuju li se procjene prihvatljivosti kršenja moralnih normi ovisno o tome odgovaramo li na moralne dileme na materinskom ili stranom jeziku, odnosno postoji li efekt stranog jezika na procjenjivanje

etičnosti postupanja u različitim situacijama. Željeli smo zahvatiti širok spektar moralnih dvojbi, od onih svakodnevnih, koje se mogu dogoditi bilo kojem pojedin$\mathrm{cu}$, do onih koje su rijetke i traže odlučivanje o životima ljudi. Također, scenarije smo razlikovali s obzirom na stupanj težine kršenja moralnih normi. 
Pretpostavili smo da će sudionici kršenje moralnih normi smatrati manje prihvatljivim kada budu odgovarali na materinskom jeziku nego kada budu odgovarali na stranom jeziku. Ta će razlika biti vidljiva i u rezultatima upitnika koji opisuje svakodnevne situacije, kao i kod procjena situacija koje predstavljaju tek hipotetske scenarije. Razlike u procjenama prihvatljivosti postupka opisanog u scenariju nismo očekivali kod moralno neutralnog scenarija, a očekivali smo ih kod ostalih, bez obzira na težinu opisanog moralnog prijestupa.

\section{Metoda}

\subsection{Sudionici}

$\mathrm{U}$ istraživanju je sudjelovalo 93 studenata germanistike, s različitih godina studija. U nastojanju osiguravanja anonimnosti sudionika nismo tražili podatak o njihovoj dobi i spolu, ali možemo pretpostaviti da se u uzorku našlo više studentica nego studenata jer je ispitivanje provedeno $\mathrm{u}$ sklopu redovite nastave na studiju, a studij germanistike upisuje više žena nego muškaraca. Sudionici koji su ispunjavali upitnik na njemačkom jeziku $(N=52)$ procijenili su koliko su razumjeli sadržaj upitnika kao i vlastito znanje njemačkog jezika. Razumijevanje su procjenjivali na skali od 1 (nimalo) do 7 (u potpunosti), a znanje jezika na skali od 1 (vrlo loše) do 7 (odlično). Prosječna procjena razumijevanja je iznosila $M=6,63(S D=0,668)$, a znanja jezika $M=5,66(S D=1,206)$. Pri tome je najmanja dobivena procjena razumijevanja bila 4, a znanja jezika 3. S obzirom na ovako visoke procjene, svi sudionici su zadržani u daljnjoj analizi podataka.

\subsection{Instrumenti}

U istraživanju je primijenjen Upitnik svakodnevnog morala i socijalnih normi (Khemiri, Guterstam, Franck i Jayaram-Lindström 2012, a kojim su se koristili i Geipel, Hadjichristidis i Surian, 2015b). U njemu se od sudionika tražilo da za niz od 15 rečenica, koje opisuju različite radnje, odgovore koliko je pogrešno ono što je u njima opisano. Odgovore su davali zaokruživanjem broja na skali od 0 do 3 pri čemu je 0 značilo potpuno je u redu, a 3 je značilo potpuno je pogrešno. Na primjer, trebalo je procijeniti koliko je pogrešno »voziti nakon što ste popili jedno alkoholno piće« ili koliko je pogrešno »zadržati ostatak pogrešno vraćenog novca u dućanu«. Sve rečenice koje su sudionici procjenjivali nalaze se u Prilogu 1. Pouzdanost upitnika izražena Crombachovim alpha koeficijentom iznosila je 0,75.

Nakon toga, sudionici su imali zadatak procjene kratkih priča, odnosno scenarija u kojima su opisane moralne dvojbe. Odgovore su davali na skali od 0 do 6 pri čemu je 0 značilo da je ono što je opisano u priči posve u redu, dok je 6 značilo da je opisano posve pogrešno. Prva tri scenarija opisivala su svakodnevne događaje u kojima su opisani moralni prekršaji različitog stupnja težine. Ovi scenariji su oda- 
brani na temelju predistraživanja u kojem je 36 studenata psihologije $s$ istog fakulteta procijenilo stupanj težine moralnih prekršaja opisanih u većem broju scenarija. Ovim korakom htjeli smo osigurati odabir scenarija koji predstavljaju različite stupnjeve kršenja moralnih normi u našoj kulturi s obzirom na to da je moguće da bi u nekim drugim kulturama ovi scenariji bili procijenjeni kao veći ili manji moralni prekršaji. Prvi scenarij je zapravo bio moralno neutralan, a opisivao je ženu koja odlučuje hoće li putovati jeftinijim i lošijim ili skupljim i udobnijim vlakom. Druga je priča opisivala blaži moralni prijestup, odnosno situaciju prepisivanja na ispitu, nakon čega nije bilo loših posljedica ni za onoga koji je prepisivao ni za onoga od kojeg se prepisivalo, a treća je priča opisivala situaciju većeg moralnog prijestupa u kojoj akter u financijskim problemima nalazi novčanik s puno novca i razmišlja o tome da ga ne vrati vlasniku. Priče su preuzete iz prethodnih istraživanja i nalaze se u Prilogu 2.

Nakon toga je slijedilo pet scenarija u kojima su opisane situacije u kojima treba odlučiti je li u redu odabrati smrt jedne osobe kako bi se spasili životi preostalih pet ili šest osoba. Radi se o poznatim pričama upotrijebljenim u mnogim istraživanjima donošenja moralnih odluka. Zadatak sudionika, kao i kod prve tri priče, bio je procijeniti koliko je opisana utilitarna odluka (žrtvovati jednu osobu kako bi se spasili preostali ljudi) moralno pogrešna. Scenariji se nalaze u Prilogu 2.

Primijenjene su dvije verzije upitnika, jedna na hrvatskom, a druga na njemačkom jeziku. Upitnici su bili posve jednaki, osim što je upitnik na njemačkom sadržavao dva dodatna pitanja o razumijevanju sadržaja upitnika i znanju njemačkog jezika.

\subsection{Postupak}

Ispitivanje je provedeno u svibnju 2018. godine u sklopu redovite nastave na studiju. Svi sudionici su prije početka ispitivanja pročitali i potpisali Pristanak na sudjelovanje u kojem je pisalo da je riječ o istraživanju donošenja odluka u različitim situacijama, da je istraživanje u potpunosti anonimno i da mogu od njega u bilo kojem trenutku odustati. Oni koji su odlučili sudjelovati u istraživanju su nakon toga dobili upitnik čije je ispunjavanje trajalo otprilike 10 minuta. Upitnici su podijeljeni po slučaju i to tako da je otprilike polovica sudionika u svakoj skupini dobila tekst na njemačkom, a polovica na hrvatskom jeziku. Nakon što su ispunili upitnik, sudionicima je objašnjena svrha istraživanja.

\section{Rezultati}

Odgovori sudionika na tri priče u kojima su opisani moralni prekršaji različitog stupnja težine prikazani su u Tablici 1. Kako je moguće vidjeti iz prikazanih rezultata, prosječan rezultat sudionika koji su odgovarali na hrvatskom jeziku viši je od prosječnog rezultata onih koji su odgovarali na njemačkom u slučaju manje (ispit) i veće (novčanik) moralne dileme, dok razlike nema kad je u pitanju neutralan sce- 
narij (vlak). Drugim riječima, sudionici koji su odgovarali na materinskom jeziku u većoj su mjeri opisane moralne prekršaje smatrali pogrešnima od sudionika koji su odgovarali na stranom jeziku.

\begin{tabular}{|l|l|l|}
\hline & \multicolumn{2}{|c|}{ Jezik } \\
\hline & \multicolumn{1}{|c|}{ hrvatski } & \multicolumn{1}{c|}{ njemački } \\
\hline Neutralna (vlak) & $0,73(1,245)$ & $0,77(1,262)$ \\
\hline Manji prekršaj (ispit) & $3,24(1,841)$ & $2,25(1,748)$ \\
\hline Veći prekršaj (novčanik) & $4,93(1,523)$ & $4,46(1,789)$ \\
\hline
\end{tabular}

Tablica 1. Procjene veličine moralnog prekršaja (aritmetičke sredine i standardne devijacije) sudionika koji su odgovarali na hrvatskom ( $N=41)$ i na njemačkom jeziku (N=52) ovisno o stupnju težine moralnog prekršaja koji je opisan u priči

Kako bismo provjerili postoji li statistički značajna razlika u procjenama moralnosti ovisno o jeziku i težini moralnog prekršaja kod ovih scenarija, proveli smo složenu analizu varijance u kojoj je jedna nezavisna varijabla bila jezik (materinski ili strani), a druga vrsta priče (neutralna, manji prekršaj, veći prekršaj). Rezultati su pokazali značajan glavni efekt vrste dileme, odnosno težine moralnog prekršaja $\left(F(2 / 182)=176,9 ; p<, 01 ; \eta^{2}=0,65\right)$, značajan glavni efekt jezika $(F(1 / 91)=4,3$; $\left.p<, 05 ; \eta^{2}=0,045\right)$ i značajnu interakciju $\left(F(2 / 182)=3,03 ; p=, 05 ; \eta^{2}=0,01\right)$. To znači da su sudionici koji su odgovarali na hrvatskom jeziku davali strože procjene opisane situacije, u smislu da su smatrali da je ona više pogrešna nego sudionici koji su odgovarali na njemačkom jeziku. Procjena je ovisila i o priči i to na način da je najprihvatljivijom procijenjena priča o vlaku, zatim ona o ispitu, a najmanje je prihvatljivom procijenjena situacija s novčanikom. Opisani rezultati u skladu su s očekivanjima i prijašnjim nalazima istraživanja. Interakcija jezika i vrste priče govori o nejednakom efektu jezika na sve priče - razlike u procjenama ovisno o jeziku nema kada se radi o neutralnoj priči, a postoji u situacijama kada je opisana neka moralna dilema. Post-hoc testovima provjerili smo postojanje razlike u moralnim procjenama na različitim jezicima za svaku od tri priče. Kao što se vidi iz prosječnih procjena prikazanih u Tablici 1., a to potvrđuje i post-hoc test, ne postoji statistički značajna razlika u procjenama neutralne priče na hrvatskom i njemačkom jeziku ( $F$ $=0,02 ; p>, 05)$. U priči u kojoj postoji moralna dilema, ali situacija nije procijenjena kao izrazito veliki moralni prekršaj, postoji očekivana razlika u procjenama ovisno o jeziku na kojem su sudionici odgovarali $(F=7,07 ; p<, 01)$ i to tako da su procjene na hrvatskom jeziku značajno više, odnosno situacija je procijenjena kao više pogrešna nego u slučaju procjena na njemačkom jeziku. I konačno, razlika u procjenama na hrvatskom i njemačkom jeziku za priču koja opisuje veći moralni prekršaj nije se pokazala statistički značajnom $(F=4,96 ; p>, 05)$. Možemo zaključiti da efekt stranog jezika na procjene moralnosti postoji onda kada se radi o moralnim prekr- 
šajima srednje veličine, dok za veće moralne prekršaje dajemo slične odgovore bez obzira na jezik na kojem odgovaramo.

Nadalje, usporedili smo rezultate sudionika koji su odgovarali na hrvatskom i njemačkom jeziku na pet scenarija u kojima se tražila procjena ispravnosti donošenja odluke o žrtvovanju jedne osobe kako bi se spasilo više ljudi. Kako je vidljivo iz rezultata prikazanih u Tablici 2., Levenov test jednakosti varijanci pokazao je da ne postoji razlika u varijancama skupina koje su odgovarale na njemačkom i na hrvatskom jeziku, osim u slučaju scenarija o taocima $(F=5,12 ; p<, 05)$. Stoga su razlike u dobivenim aritmetičkim sredinama ispitane t-testom za nezavisne uzorke, osim u slučaju scenarija o taocima kada je prikazan rezultat Welchova t-testa koji uzima u obzir nejednakost varijanci.

\begin{tabular}{|c|c|c|c|c|c|c|}
\hline & & $M$ & $S D$ & $N$ & $t$ & Cohenovd \\
\hline \multirow[t]{2}{*}{ Taoci } & hrvatski & 3.70 & 2.003 & 40 & \multirow[t]{2}{*}{$2.014^{*}$} & \multirow[t]{2}{*}{0.433} \\
\hline & njemački & 2.90 & 1.706 & 52 & & \\
\hline \multirow{2}{*}{$\begin{array}{l}\text { Podmor- } \\
\text { nica }\end{array}$} & hrvatski & 4.05 & 1.679 & 40 & \multirow[t]{2}{*}{$2.799^{* *}$} & \multirow[t]{2}{*}{0.589} \\
\hline & njemački & 3.04 & 1.749 & 52 & & \\
\hline \multirow[t]{2}{*}{ Vojnici } & hrvatski & 3.95 & 1.724 & 40 & \multirow[t]{2}{*}{$2.880^{* *}$} & \multirow[t]{2}{*}{0.606} \\
\hline & njemački & 2.90 & 1.729 & 52 & & \\
\hline \multirow[t]{2}{*}{ Brod } & hrvatski & 4.53 & 1.450 & 40 & \multirow[t]{2}{*}{$3.710^{* *}$} & \multirow[t]{2}{*}{0.784} \\
\hline & njemački & 3.20 & 1.866 & 51 & & \\
\hline \multirow{2}{*}{$\begin{array}{l}\text { Nadvo- } \\
\text { žnjak }\end{array}$} & hrvatski & 4.95 & 1.319 & 40 & \multirow[t]{2}{*}{1.127} & \\
\hline & njemački & 4.57 & 1.792 & 51 & & \\
\hline
\end{tabular}

${ }^{*} p<, 05 ;{ }^{* *} p<, 01$

Tablica 2. Procjene ispravnosti donošenja utilitarne odluke u pet različitih scenarija za sudionike koji su odgovarali na hrvatskom i njemačkom jeziku

U skladu s očekivanjima, t-testovi pokazuju da su procjene sudionika koji su odgovarali na hrvatskom jeziku značajno više od procjena sudionika koji su odgovarali na njemačkom jeziku kod svih opisanih scenarija osim jednog. To znači da su sudionici koji su odgovarali na hrvatskom procijenili opisanu utilitarnu odluku više pogrešnom nego sudionici koji su odgovarali na njemačkom jeziku. Iznimku predstavlja scenarij u kojem se od sudionika traži da procijeni koliko je pogrešno gurnuti jednu osobu pod vlak kako bi spasili živote pet ljudi. Ta je odluka ujedno procijenjena najpogrešnijom. Kao i u slučaju prva tri scenarija, možemo zaključiti da se efekt stranog jezika javlja onda kada je opisan moralni prijestup srednje težine, ali ne i onda kada se radi o težim prekršajima.

Konačno, provjerili smo postoji li razlika u rezultatima na Upitniku svakodnevnog morala i socijalnih normi između sudionika koji su odgovarali na hrvatskom i 
onih koji su odgovarali na njemačkom jeziku. Ukupni rezultat na Upitniku svakodnevnog morala i socijalnih normi izračunat je kao prosjek odgovora na svim česticama. Iako smo očekivali da će procjene biti više u situaciji odgovaranja na hrvatskom jeziku, odnosno da će sudionici koji su na pitanja odgovarali na hrvatskom jeziku u većoj mjeri osuđivati navedene moralne prekršaje, $\mathrm{t}$-test je pokazao da nema statistički značajne razlike u procjeni koliko su opisane radnje pogrešne između sudionika koji su odgovarali na hrvatskom $(M=1,67 ; S D=0,342)$ i onih koji su odgovarali na njemačkom jeziku $(M=1,76 ; S D=0,456 ; \mathrm{t}=1,12 ; d f=91 ; p>, 05)$.

\section{Rasprava}

Rezultati dosad provedenih istraživanja upućuju na to da donosimo različite (moralne) odluke ovisno o tome koristimo li se pri donošenju odluke materinskim ili stranim jezikom. U ovom istraživanju željeli smo provjeriti razlikuju li se procjene prihvatljivosti kršenja moralnih normi ovisno o tome odgovaramo li na moralne dileme na materinskom ili stranom jeziku, uzimajući pri tom u obzir i stupanj težine moralnog prekršaja. Kako bismo pokušali ponoviti nalaze prethodnih istraživanja koja su provedena u drugim zemljama i na drugim jezicima, uključili smo moralne dileme koje se tipično mogu naći u istraživanjima u ovom području. U tim scenarijima su opisane situacije u kojima se ljudi mogu naći iznimno rijetko ili nikada u životu, što ujedno predstavlja najznačajniji prigovor tim istraživanjima jer čini mogućnost njihove primjene upitnom. Zbog toga smo u istraživanje uključili i scenarije u kojima se opisuju dileme u kojima se prosječna osoba može naći u svakodnevnom životu. U cjelini, rezultati istraživanja pokazuju da se procjene prihvatljivosti kršenja moralnih normi razlikuju ovisno o tome odgovaramo li na moralne dileme na materinskom ili na stranom jeziku, ali ne u svim scenarijima u kojima smo to očekivali. Rezultati, dakle, nisu u potpunosti u skladu s očekivanjem da će efekt stranog jezika biti prisutan u svim scenarijima osim u moralno neutralnom scenariju, no uzeti zajedno, dobiveni rezultati mogu se smisleno interpretirati.

Ovo istraživanje razlikovalo se od drugih dosad provedenih po tome što smo razlikovali težinu moralnih prekršaja opisanih u scenarijima. Jedan scenarij uopće nije sadržavao moralnu dvojbu (vlak), drugi je opisivao situaciju manjeg moralnog prekršaja (ispit), a posljednji je opisivao veći prekršaj (novčanik). Potpuno očekivano, procjene prihvatljivosti postupaka opisanih u scenarijima su se razlikovale s obzirom na težinu moralnog prijestupa. S porastom težine prijestupa postupci su procjenjivani sve manje prihvatljivima. Nadalje, postupci opisani u scenarijima procijenjeni su manje prihvatljivima na materinskom nego na stranom jeziku. $U$ skladu s očekivanjima, procjene prihvatljivosti postupka opisanog u neutralnoj dilemi nisu se razlikovale s obzirom na jezik na kojem je dilema prezentirana. Ovakav nalaz zapravo upućuje na to da su sudionici koji su odgovarali na stranom jeziku razumjeli sadržaj i način odgovaranja. Naime, ovo je jedini scenarij na koji zapravo postoji točan odgovor. Postupak opisan u scenariju ni po čemu nije moralno dvoj- 
ben. Također u skladu s očekivanjima, procjene prihvatljivosti manjeg moralnog prekršaja razlikovale su se s obzirom na to na kojem su jeziku sudionici odgovarali. Prepisivanje na ispitu procijenjeno je prihvatliivijim na stranom nego na materinskom jeziku. Konačno, suprotno očekivanjima, procjene prihvatljivosti većeg moralnog prekršaja nisu se razlikovale s obzirom na jezik. I na materinskom i na stranom jeziku postupak opisan u ovom scenariju sudionici su procjenjivali jednako neprihvatljivim.

U drugom dijelu istraživanja koristili smo se scenarijima kakvi se tipično koriste u istraživanjima koja se bave efektom stranog jezika. Scenariji opisuju ekstremne situacije, a zadatak sudionika je procijeniti koliko je u takvom slučaju prihvatljiva utilitarna odluka o žrtvovanju jedne osobe kako bi se spasilo pet ili šest ljudi. Očekivali smo da će efekt stranog jezika postojati u svim ovakvim scenarijima, no $\mathrm{u}$ jednom scenariju o nadvožnjaku on je izostao. Ovakav nalaz nije u skladu s postojećom literaturom u kojoj je ovo jedan od najčešće primjenjivanih scenarija te se na njemu gotovo redovito pokazuje efekt stranog jezika. Ipak, naše se istraživanje razlikovalo od drugih u tome kakvi su scenariji bili uključeni. Sudionici u drugim istraživanjima su često odgovarali samo na scenarij »nadvožnjak«, a kada su bili uključeni i drugi scenariji, oni nisu slijedili istu ovakvu formu u kojoj se procjenjuje ispravnost utilitarne odluke. Suprotno tome, u ovom je istraživanju "nadvožnjak« jedan u nizu scenarija u kojem se suprotstavlja utilitarno i deontološko načelo, ali jedini scenarij u kojem je sasvim sigurno da će krupna osoba preživjeti ako je sudionik ne žrtvuje. Životi likova u svim drugim scenarijima ugroženi su i prije nego sudionik odluči hoće li ih žrtvovati ili ne. Zbog toga su sudionici, u kontekstu preostalih scenarija, žrtvovanje života koji inače nije ugrožen mogli procijeniti neprihvatljivijim od žrtvovanja osobe za koju nije sigurno hoće li preživjeti ni ako je ne žrtvujemo. Ovu pretpostavku podržavaju aritmetičke sredine procjena prihvatljivosti u scenariju »nadvožnjak« - one ukazuju na bitno veću neprihvatljivost žrtvovanja postupka opisanog u ovom scenariju u odnosu na druge scenarije iz ove skupine. Procjene neprihvatljivosti u scenariju »nadvožnjak« usporedive su s procjenama neprihvatljivosti postupka u scenariju »novčanik« koji je odabran kao primjer velikog moralnog prekršaja u prvom dijelu istraživanja. Procjene neprihvatljivosti postupaka opisanih u ostalim scenarijima iz ove skupine su niže te su usporedive s procjenom blažeg prekršaja (ispit) iz prethodne skupine scenarija. Dakle, i ovaj put je efekt stranog jezika postojao u scenarijima koji su općenito procijenjeni nešto blaže, a u izrazito neprihvatljivom scenariju efekta nije bilo.

Konačno, u Upitniku svakodnevnog morala i socijalnih normi bile su opisane moralno dvojbene situacije koje nisu ekstremne i s kojima se većina ljudi redovito susreće. Suprotno očekivanjima, efekt stranog jezika u ovim se scenarijima nije pokazao. I u ovom je slučaju, međutim, zanimljivo usporediti aritmetičke sredine procjena neprihvatljivosti postupaka opisanih u ovom upitniku s procjenama iz prve skupine scenarija. Procjene scenarija iz Upitnika svakodnevnog morala i socijalnih normi vrlo su niske, odnosno usporedive su s procjenama neutralnog scenarija 
(vlak). Mogli bismo reći da sudionici situacije iz ovog upitnika uglavnom ne smatraju moralno upitnima pa je ovakav nalaz u skladu s očekivanjem da u moralno neutralnim scenarijima neće biti efekta stranog jezika te je u skladu s rezultatima dobivenim na scenariju "vlak«. Uvidom u upitnik jasno je da je u nekim česticama opisan postupak kojim se krši neko moralno načelo (npr. "prodati nekome neispravan automobil ), dok je u drugim česticama opisan postupak koji se zapravo ne krši moralno načelo, iako je postupanje obrnuto navedenom pohvalno (npr. »ne darivati krv«).

Ukupno, rezultati ovog istraživanja ipak idu u prilog postojanju efekta stranog jezika. Čini se da pritom nije važno opisuju li scenariji svakodnevne ili rijetke i ekstremne događaje. Efekt je u nekim scenarijima koji opisuju svakodnevne događaje postojao, a u drugima je izostao, a isto je vrijedilo i za ekstremne scenarije. Čini se da umjesto toga važnu ulogu u tome hoće li se efekt stranog jezika pojaviti ili neće igra stupanj težine moralnog prekršaja. Tako efekt izostaje u scenarijima koje jasno prepoznajemo kao neispravne i u onima koje smatramo neutralnima, a prisutan je u scenarijima koji opisuju blaže moralne prekršaje.

Dobiveni rezultati mogu se interpretirati u skladu s rastućom literaturom koja podupire objašnjenje da do efekta stranog jezika dolazi zbog toga što su na stranom jeziku emocije suprimirane (Hayakawa i sur. 2017). Pretpostavka je, dakle, da je intenzitet emocionalne reakcije povezan s percipiranom težinom moralnog prijestupa, a onda i s time kakvu ćemo odluku donijeti. Efekt stranog jezika može se objasniti pretpostavimo li da postoji određeni intenzitet neugodnih emocija koji treba biti doživljen kako bismo postupak prepoznali kao nemoralan, odnosno kao veliko kršenje moralnih načela i kako ga ne bismo odobravali. Ako intenzitet neugodnih emocija nije dovoljan, onda postupak ne prepoznajemo jasno kao neprihvatljiv. Tako neutralni scenariji i scenariji koji opisuju zaista blage moralne prekršaje i na materinskom jeziku izazivaju izrazito slabe emocije. U tom je slučaju intenzitet emocija usporediv sa suprimiranim emocijama na stranom jeziku i efekt stranog jezika izostaje. Veliki moralni prekršaji na materinskom jeziku izazivaju izrazito intenzivne neugodne emocije koje upotreba stranog jezika oslabi, ali su one i dalje dovoljno intenzivne da određeni postupak prepoznamo kao neprihvatljiv pa efekt stranog jezika ni u ovom slučaju ne postoji. Efekt stranog jezika međutim postoji kod srednje veličine moralnih prekršaja. U tom slučaju je emocionalna reakcija na materinskom jeziku dovoljno intenzivna da se postupak prepozna kao neprihvatljiv, a na stranom jeziku je intenzitet emocija suprimiran, ne dostiže minimalan potreban intenzitet da se postupak jasno okarakterizira kao neprihvatljiv i tada se javlja efekt stranog jezika.

Iako se objašnjenje koje nudimo uklapa u objašnjenje efekta stranog jezika temeljeno na manjoj emocionalnosti stranog jezika, važno je naglasiti da u ovom istraživanju nismo mjerili intenzitet emocija. Iako se u ranijim istraživanjima emocije nisu pokazale kao medijator veze između moralnih odluka i efekta stranog jezika (Geipel, Hadjichristidis i Surian 2015a), naglašavamo da do sada u istraživanjima efekta stranog jezika nisu mjerene moralne emocije poput srama ili krivnje koje 
pružaju izravne informacije o moralnoj prihvatljivosti određenog postupka (Cipolletti, McFarlane i Weissglass 2016), već su mjerene jednostavne neugodne emocije poput ljutnje i tuge. Osim toga, u budućim istraživanjima bilo bi dobro i koristiti više scenarija koji opisuju neutralne postupke te blaže i teže moralne prijestupe s kojima se sudionici mogu susresti u svakodnevnom životu.. Konačno, bilo bi korisno u budućim istraživanjima mjeriti stvarno ponašanje (npr. laganje ili varanje), a ne samo izvještaje o tome kako bi sudionici postupili u hipotetskim situacijama.

Praktične implikacije efekta stranog jezika su mnogobrojne (Caldwell-Harris 2015). Postojanje razlika u ishodima i mehanizmima donošenja odluka na materinskom i stranom jeziku potiče na čitav niz pitanja: Jesu li upozorenja o klimatskim promjenama jednako učinkovita na stranom jeziku kao i na materinskom, ako se pokazalo da ljudi rizike procjenjuju nižima na stranom jeziku? Je li bolje da je reklama za tehničku opremu na stranom jeziku, a reklama koja treba pobuditi emocije na materinskom, ako znamo da su reklamni slogani procijenjeni emocionalnijima na materinskom jeziku (Puntoni, De Langhe i Van Osselar 2009)? Može li se manja emocionalnost stranog jezika iskoristiti u terapijske svrhe, jer će strani jezik olakšati razgovor o traumatskim iskustvima? Je li poligraf dobar indikator iskrenosti ako se ispitivanje provodi na stranom jeziku (Caldwell-Harris i Ayçiçegi-Dinn 2009)? Do sada provedena istraživanja upućuju na to da o mogućem utjecaju jezika svakako treba voditi računa, ali je i jasno da je potrebno precizirati uvjete u kojima se efekt pojavljuje, kao i njegove dosege.

\section{Literatura}

Anooshian, L. i Hertel, P. (1994). Emotionality in free recall: Language specificity in bilingual memory. Cognition \& Emotion 8: 503-514, https://doi.org/10.1080/02699939408408956

Bond, M. H.i Lai, T. M. (1986). Embarrassment and code-switching into a second language. Journal of Social Psychology 126: 179-186

Caldwell-Harris, C. L. (2015). Emotionality differences between a native and foreign language: Implications for everyday life. Current Directions in Psychological Science 24: 214 219, http://dx.doi.org/10.1177/0963721414566268

Caldwell-Harris, C. L. i Ayçiçegi-Dinn, A. (2009). Emotion and lying in a non-native language. International Journal of Psychophysiology 71: 193-204, http://dx.doi.org/10.1016/j.ijpsycho.2008.09.006

Cipolletti, H., McFarlane, S. i Weissglass, C. (2016). The moral foreign-language effect. Philosophical Psychology 29(1): 23-40, http://dx.doi.org/10.1080/09515089.2014.993063

Colbeck, K. L. i Bowers, J. S. (2012). Blinded by taboo words in L1 but not L2. Emotion 12: 217-222, http://dx.doi.org/10.1037/a0026387

Costa, A., Foucart, A., Arnon, I., Aparici, M. i Apesteguia, J. (2014). »Piensa« twice: On the foreign language effect in decision making. Cognition 130: 236-254, http://dx.doi.org/10.1016/j.cognition.2013.11.010 
Costa, A., Foucart, A., Hayakawa, S., Aparici, M., Apesteguia, J., Heafner, J. i Keysar, B. (2014). Your morals depend on language. PLoS one 9: e94842, http://dx.doi.org/10.1371/journal.pone.0094842

Costa, A., Corey, J. D., Hayakawa, S., Aparici, M., Vives, M.-L. i Keysar, B. (2019). The role of intentions and outcomes in the foreign language effect on moral judgements. Quarterly Journal of Experimental Psychology 72(1): 8-17, http://dx.doi.org/10.1177/1747021817738409

Čavar, F. i Tytus, A. E. (2017). Moral judgement and foreign language effect: when the foreign language becomes the second language. Journal of Multilingual and Multicultural Development 39(1): 17-28, https://doi.org/10.1080/01434632.2017.1304397

Eilola, T. M., Havelka, J. i Sharmaa, D. (2007). Emotional activation in the first and second language. Cognition and Emotion 21: 1064-1076, https://doi.org/10.1080/02699930601054109

Eilola, T. M. i Havelka, J. (2011). Behavioural and physiological responses to the emotional and taboo Stroop tasks in native and non-native speakers of English. International Journal of Bilingualism 15: 353-369, https://doi.org/10.1177/1367006910379263

Eurostat (2019.). Foreign language skills statistics. Dana 15. 7. 2019. na: https:// ec.europa.eu/eurostat/statistics-explained/index.php/Foreign_language_skills_ statistics\#Number_of_foreign_languages_known

Eyal, T., Liberman, N. i Trope, Y. (2008). Judging near and distant virtue and vice. Journal of Experimental Social Psychology 44: 1204-1209, https://doi.org/10.1016/j.jesp.2008.03.012

Fujita, K., Henderson, M.D., Eng, J., Trope, Y. i Liberman, N. (2006). Spatial distance and mental construal of social events. Psychological Science 17(4): 278-82, http://dx.doi.org/10.1111/j.1467-9280.2006.01698.x

Gao, S., Zika, O., Rogers, R. D. i Thierry, G. (2015). Second language feedback abolishes the »hot hand « effect during even-probability gambling. Journal of Neuroscience 35(15): 5983-9, https://doi.org/10.1523/JNEUROSCI.3622-14.2015

Greene, J. D., Sommerville, R. B., Nystrom, L. E., Darley, J. M., i Cohen, J. D. (2001). An fMRI investigation of emotional engagement in moral judgment. Science 293: 2105-2108, https://doi.org/10.1126/science.1062872

Geipel, J., Hadjichristidis, C. i Surian, L. (2015b). How foreign language shapes moral judgment. Journal of Experimental Social Psychology 59: 8-17, https://doi.org/10.1016/j.jesp.2015.02.001

Geipel, J., Hadjichristidis, C. i Surian, L. (2016). Foreign language affects the contribution of intentions and outcomes to moral judgment. Cognition 154: 34-39, https://doi.org/10.1016/j.cognition.2016.05.010

Hadjichristidis, C., Geipel, J.iSavadori, L. (2015). The effect of foreignlanguage in judgments of risk and benefit: The role of affect. Journal of Experimental Psychology: Applied 21: 117-129, https://doi.org/10.1037/xap0000044

Harris, C. L., Ayçiçegi, A. i Gleason, J. B. (2003). Taboo words and reprimands elicit greater autonomic reactivity in a first than in a second language. Applied Psycholinguistics 4: 561-578, https://doi.org/10.1017/S0142716403000286 
Harris, C. L., Gleason, J. B. i Ayçiçegi, A. (2006). When is a first language more emotional? Psychophysiological evidence from bilingual speakers. Pavlenko, A., ur. Bilingual minds: Emotional Experience, Expression and Representation. Clevedon: Multilingual Matters, 257-283

Hayakawa, S. i Keysar, B. (2018). Using a foreign language reduces mental imagery. Cognition 173: 8-15, http://dx.doi.org/10.1016/j.cognition.2017.12.010

Hayakawa, S., Tannenbaum, D., Costa, A., Corey, J. D. i Keysar, B. (2017). Thinking more or feeling less? Explaining the foreign-language effect on moral judgment. Psychological Science 28: 1387-1397, http://dx.doi.org/10.1177/0956797617720944

Keysar, B., Hayakawa, S. i An, S. (2012). The foreign language effect: Thinking in a foreign tongue reduces decision biases. Psychological Science 23: 661-668, http://dx.doi.org/10.1177/0956797611432178

Khemiri, L., Guterstam, J., Franck, J. i Jayaram-Lindström, N. (2012). Alcohol dependence associated with increased utilitarian moral judgment: A case control study. PLoS one 7: e39882, http://dx.doi.org/10.1371/journal.pone.0039882

Pavlenko, A. (2012). Affective processing in bilingual speakers: disembodied cognition? International Journal of Psychology 47(6): 405-28, http://dx.doi.org/10.1080/00207594.2012.743665

Puntoni, S., De Langhe, B. i Van Osselaer, SM. J. (2009). Bilingualism and the emotional intensity of advertising language. Journal of Consumer Research 35: 1012-1025, http://dx.doi.org/10.1086/595022

Rasanen, S. H. M. R. i Pine, J. M. (2012). Emotional force of languages in multilingual speakers in Finland. Applied Psycholinguistics 35: 443-471, https://doi.org/10.1017/S0142716412000471

Sheikh, N. A. i Titone, D. (2015). The embodiment of emotional words in a second language: An eye-movement study. Cognition and Emotion 30(3): 488-500, https://doi.org/10.1080/02699931.2015.1018144

Thomson, J. J. (1985). The trolley problem. Yale Law Journal 94: 1395-1415, http://dx.doi.org/10.2307/796133 


\section{Foreign language effect and moral decision making}

Foreign language effect (FLE) refers to different outcomes of the decision-making process depending on whether it is carried out in a native or a foreign language. The aim of this study was to examine whether the FLE is present in the assessment of moral wrongness of behaviour in different scenarios. Put differently, the aim was to examine whether the language in which the moral dilemma was presented influenced ratings of acceptability of violating moral norms. Dilemmas used in the research described a wide range of situations ranging from the ones that could be faced in everyday life to the situations in which decisions about people's lives had to be made and differed in degree of violation of moral norms they described. The study participants, students of German Language and Literature from the Faculty of Humanities and Social Sciences in Zagreb, were divided into two groups: one group completed the questionnaire in Croatian, while the other group completed it in German. The questionnaire consisted of three parts: a Questionnaire of Everyday Morality and Social Norms, three moral dilemmas describing moral misdeeds of varying degrees, and scenarios describing situations in which it was necessary to decide on the lives of people. The task of the participant was to rate the moral wrongness of the described behaviour. The results show that FLE was present in mild moral offences as well as when it was necessary to decide on the lives of people-participants who assessed violating moral norms in the Croatian language rated them as less acceptable than those who assessed the same violations in German. The effect was not present for great moral offense nor in the Questionnaire of Everyday Morality and Social Norms.

Ključne riječi: efekt stranog jezika, etičnost odluka, strani jezik

Keywords: foreign language effect, ethics of decision making, foreign language 


\section{Prilog 1.}

Upitnik svakodnevnog morala i socijalnih normi (Khemiri, Guterstam, Franck i Jayaram-Lindström, 2012). Zadatak sudionika je bio da na skali od 0 (potpuno je u redu) do 3 (potpuno je pogrešno) procijene koliko je pogrešno učiniti ono što je napisano.

Prema Vašem mišljenju, kolikoje pogrešno...

1. ne ispuniti malo obećanje.

2. zauzeti posljednje sjedalo u punom autobusu.

3. prodati nekome neispravan automobil.

4. voziti nakon što ste popili jedno alkoholno piće.

5. progurati se u redu kada nam se žuri.

6. ne darivati krv.

7. biti neugodan prema nekome tko nam se ne sviđa.

8. reći bijelu laž kako bi kazna bila blaža.

9. istjerati beskućnike iz svog susjedstva.

10. ne pomoći nekome da pokupi papire koji su mu ispali.

11. zadržati ostatak pogrešno vraćenog novca u dućanu.

12. ne ponuditi pomoć nakon nesreće.

13. ignorirati nepoznatu osobu koja je gladna.

14. ne glasati na izborima.

15. zadržati novac pronađen na ulici.

\section{Prilog 2.}

Moralne dileme upotrijebljene u istraživanju i uputa sudionicima.

Pred Vama se nalazi niz priča. Vaš je zadatak da svaku od njih pažljivo pročitate i odgovorite kolikoje pogrešno ono što se u priči dogodilo.

Pri tome Vas molimo da koristite skalu od 0 do 6 pri čemu 0 znači potpuno u redu, a 6 znači potpuno pogrešno.

Vlak (Greene i sur. 2001)

Želite posjetiti jednog od svojih prijatelja koji živi u drugom gradu. Ako putujete boljim vlakom, morate platiti veću cijenu, ali vlak je vrlo udoban. Ako umjesto toga putuje regionalnim vlakom platit ćete manje, ali vagoni su u tom vlaku malo hladni i prljavi. Odabirete putovati regionalnim vlakom.

Ispit (Eyal, Liberman i Trope 2008)

Na ispitu ste i ne znate odgovore na neka pitanja pa ih prepišete od kolege koji sjedi ispred Vas. Nisu Vas uhvatili te ćete i Vi i drugi student dobiti dobru ocjenu.

Novčanik (Greene i sur. 2001)

Šetate ulicom kada naiđete na novčanik koji leži na tlu. Otvorite novčanik i vidite da je u njemu nekoliko stotina eura u gotovini, a unutra je i vlasnikova vozačka 
dozvola. Po kreditnim karticama i drugim stvarima u novčaniku vrlo je jasno da je vlasnik novčanika bogat. Vi, s druge strane, u zadnje vrijeme imate materijalnih teškoća i novac bi Vam dobro došao. Razmišljate o tome da vlasniku vratite novčanik, a da novac zadržite za sebe.

\section{Taoci (Greene i sur. 2001)}

Putujete s pet drugih mirotvoraca kroz ratom razorenu zemlju kada vašu skupinu grupa terorista zarobi kao taoce. Nakon tjedan dana, zahtjevi terorista nisu ispunjeni i nude vam izbor: ili će vas sve ubiti ili ako Vi ubijete jednog od svojih kolega taoca, vi i ostali bit ćete slobodni. Je li pogrešno da ubijete kolegu taoca kako bi spasili sebe i druge mirotvorce?

\section{Podmornica (Greene i sur. 2001)}

Vi ste kapetan male vojne podmornice koja putuje ispod velikog ledenog brijega. Eksplozija na brodu dramatično je smanjila zalihu kisika i ozlijedila je člana posade. Mogao bi umrijeti od posljedica te ozljede. Preostali kisik nije dovoljan za svih šestero članova posade da izađu na površinu. Ako upucate ozlijeđenog člana posade bit će taman dovoljno kisika da svi ostali prežive. Je li pogrešno da upucate ozlijeđenog člana posade kako bi spasili sebe i ostale članove posade?

\section{Vojnici (Greene i sur. 2001)}

Vodite grupu vojnika koji se vraćaju iz završene misije na neprijateljskom teritoriju kada jedan od vaših ljudi stane u zamku. Ozlijeđen je, a zamka je povezana s uređajem koji upozorava neprijatelja na vašu prisutnost. Ako neprijatelj pronađe vašu grupu, svih šestero ćete umrijeti. Ako ga ostavite iza sebe, bit će ubijen, ali ostatak skupine moći će sigurno pobjeći. Je li pogrešno da ostavite vojnika u zamci iza sebe kako bi spasili sebe i ostale vojnike?

\section{Brod (prema Čavar i Tytus 2017)}

Nalazite se na malom brodu kada izbije požar i brod se mora napustiti. Budući da vaš maleni brod za spašavanje nosi više tereta od svojeg kapaciteta, sjedi opasno nisko u moru. More postaje nemirno i brod se počinje puniti vodom. Ako ne učinite nešto svih šestero na brodu ćete se utopiti. S vama je ozlijeđena osoba koja bi ionako mogla umrijeti. Ako je bacite u more, svi će ostali biti spašeni. Je li pogrešno da ozlijeđenu osobu bacite u more kako bi spasili sebe i ostale?

\section{Nadvožnjak (Thomson 1985)}

Na pruzi se ispred vlaka koji je izgubio kontrolu nad kočnicama nalazi pet željezničkih radnika koji će sigurno biti ubijeni osim ako vi, promatrač, ne nešto poduzmete. Stojite na pješačkom mostu koji prolazi preko kolosijeka i kraj vas je krupni stranac. Vaše tijelo je previše lagano da zaustavi vlak, ali ako gurnete stranca na prugu i tako ga ubijete, njegovo krupno tijelo će zaustaviti vlak. Je li pogrešno da gurnete stranca na prugu kako bi spasili željezničke radnike? 